\section{Integración docencia y extensión. Otra forma de aprender y de enseñar}

\author{
Menéndez, G. y otros (2013). Santa Fe: Ediciones
}

UNL. 98 páginas. Disponible en versión digital.

Reseñado por Valeria Boruchalski

Universidad Nacional del Litoral

vale.boruchalski@hotmail.com
Integración de la docencia y la extensión /

Reseña de libros

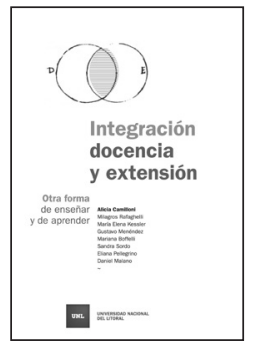

Kessler, pone el foco en las intervenciones sociales desde la extensión universitaria pensadas por la UNL y analiza en detalle los ejes estratégicos de intervención establecidos por esta casa de estudios. Por último, Gustavo Menéndez, trabaja en la dimensión comunicacional de la extensión entendida principalmente como diálogo y pone de relieve la importancia de la relación con el otro y la reflexión sobre la propia práctica.

El relato del camino recorrido por la UNL constituye el eje central de la tercera parte del libro. En ella los autores dan cuenta de las diferentes instancias de trabajo de los equipos de extensión, resaltan como puntos de partida los planes de desarrollo institucional y la creación del Área de Incorporación Curricular de la Extensión de dicha institución educativa. Explicitando el marco conceptual así como las metodologías utilizadas, el texto también abre nuevos interrogantes, esboza nuevas metas y plantea la necesidad de pensar nuevas aperturas en términos de continuidad. El cuarto apartado trabaja sobre la institucionalización e incorporación curricular de la extensión, plantea como un desafío la integración con la investigación y la docencia como parte conjunta de la vida académica que participe significativamente de los procesos de aprendizaje y enseñanza. En el escrito Gustavo Menéndez se propone profundizar la reflexión en torno a la relación universidad-sociedad haciendo foco en las principales dimensiones a partir de las cuales la UNL entiende a la extensión: dimensión sustantiva e institucional; comunicacional; social como transformación y dimensión pedagógica.

Con la pregunta por cómo deberían integrarse las funciones sustantivas de docencia, extensión e investigación para desarrollar plenamente el pensamiento crítico y la formación de ciudadanos comprometidos socialmente, el libro concluye con la propuesta de pensar y repensar la universidad. Debido a que coloca a la extensión en el centro del debate, la obra reivindica y visibiliza la riqueza conceptual y multidimensional de la extensión universitaria y pone de manifiesto el valor que posee en la educación y formación de profesionales críticos y en la construcción de sociedades más inclusivas y democráticas. 